\section{Yield Performance and Bean Quality Traits of Cacao Propagated by Grafting and Somatic Embryo-derived Cuttings}

\author{
Ricardo Goenaga ${ }^{2}$ \\ Tropical Agriculture Research Station, U.S. Department of Agriculture, \\ Agricultural Research Service, 2200 P.A. Campos Avenue, Suite 201, \\ Mayaguez, Puerto Rico 00680 \\ Mark Guiltinan and Siela Maximova
Department of Horticulture, The Pennsylvania State University, 422 Life
Sciences Building, University Park, PA 16802 \\ Ed Seguine \\ MARS, Inc., Presently Seguine Cacao Cocoa and Chocolate Advisors, 73 N. \\ Orchard View Drive, Hanover, PA 17331
}

\section{Heber Irizarry ${ }^{1}$ Mayaguez, Puerto Rico 00680 \\ Additional index words. micropropagation, cocoa, quality}

Tropical Agriculture Research Station, U.S. Department of Agriculture, Agricultural Research Service, 2200 P.A. Campos Avenue, Suite 201,

\begin{abstract}
Twelve cacao (Theobroma cacao) clones propagated by grafting and orthotropic rooted cuttings of somatic embryo-derived plants were grown on an Ultisol soil at Corozal, Puerto Rico, and evaluated for 6 years of production under intensive management. Year, variety, year $\times$ variety, and propagation treatment $\times$ variety interactions indicated significant effects for dry bean yield, number of pods produced, pod index, plant height, and stem diameter. Propagation treatments had a significant effect on dry bean yield and pod index but not on number of pods produced. Average yield across varieties for both propagation treatments was $2087.9 \mathrm{~kg} \cdot \mathrm{ha}^{-1}$ per year of dry beans. There was a highly significant variety effect. 'UF-668' was the top yielder averaging $2536.7 \mathrm{~kg} \cdot \mathrm{ha}^{-1}$ per year of dry beans; however, this yield was not significantly different from the average yield of varieties 'TARS-30', 'TARS-1', 'TARS-13', 'TARS14', and 'TARS-2', which averaged $2427.0 \mathrm{~kg} \cdot \mathrm{ha}^{-1}$ per year. Except for 'UF-668', the TARS varieties were released in 2009 as high-yielding selections. Propagation treatments had a significant effect on dry bean yield. Dry bean yield of varieties propagated by grafting was $7 \%$ higher $\left(2166.7 \mathrm{~kg} \cdot \mathrm{ha}^{-1}\right.$ per year) than those propagated by orthotropic rooted cuttings of somatic embryo-derived plants $\left(2009.2 \mathrm{~kg} \cdot \mathrm{ha}^{-1}\right.$ per year). This yield difference could not be attributed to grafted plants being more vigorous nor by differences in root architecture. The lowest pod index value in both propagation treatments was obtained by 'UF-668'; however, pod index for this variety did not differ significantly from values for 'TARS-2' and 'TARS-23' in grafted plants and from 'TARS-2', 'TARS-23', and 'TARS-1' in plants propagated by orthotropic rooted cuttings of somatic embryo-derived plants. With few exceptions, flavor characteristics were not significantly affected by propagation treatments. Although there were significant differences between plant propagation treatments for some of the variables measured in this study, these were not of a magnitude that would preclude the use of somatic embryogenesis as a viable propagation system for cacao.
\end{abstract}

\footnotetext{
Received for publication 20 Nov. 2014. Accepted for publication 27 Dec. 2014.

We thank Nicolás Díaz (deceased) and José Luis Rodríguez, Agricultural Science Research Technician, Sharon Pishak, Research Technologist, Penn State University, for their excellent assistance. Mention of trade names or commercial products in this publication is solely for the purpose of providing specific information and does not imply recommendation or endorsement of the U.S. Department of Agriculture.

${ }^{1}$ Retired.

${ }^{2}$ To whom reprint requests should be addressed; e-mail ricardo.goenaga@ars.usda.gov.
}

Cacao (Theobroma cacao) has great potential as a component of a small tropical farming system. It adapts to a wide range of soils, climatic conditions, grows well under minimum tillage, adapts to temporary intercropping, has the potential of being sold in local and export markets, and the pods are harvested year-round providing a ready source of cash income.

There is a growing demand for cacao products. The U.S. chocolate industry alone generated $\$ 19.5$ billion in sales of chocolate products in 2012 (Lindell, 2012). However, it is estimated that diseases in cacao production cause losses of potential crop amounting to $43 \%$ in America, $20 \%$ in Africa, $13 \%$ in Oceania, and 9\% in Asia (International Cocoa Organization, 2013; Willson, 1999). To satisfy future global demand for cacao products and reduce crop losses, research is needed to develop and/or identify superior cacao genotypes possessing disease tolerance and high yielding traits.

Most commercially grown cacao plantations are established from seed because this propagation method is easier and cheaper than others (Willson, 1999). However, cacao shows a high degree of segregation for many traits when propagated by seeds (Maximova et al., 2008). The production of controlled, pollinated seed using two or more parental clones may offer the opportunity to assemble into a single tree with useful traits from unrelated parents (Enriquez and Paredes, 1985; Enriquez and Soria, 1984). Others also consider the use of control-pollinated seed as the most useful means of increasing cacao production (Hunter, 1990). However, the data available to support the high yielding assumption attributed to control-pollinated seed are based only on the production obtained from a few unique segregating ' $F 1$ ' trees. The percentage of high-yielding trees resulting from controlled-pollinated ' $F_{1}$ ' progenies has been reported to be $8 \%$ to $14 \%$ (Batista, 1981; Esquivel and Soria, 1967). However, in a long-term experiment that included yield evaluation of five cacao interclonal families grown at three locations and harvesting periods lasting up to 8 years, the percentage of high-yielding trees was found to be only $3 \%$ (Irizarry and Rivera, 1998). Notably, this low percentage of high-yielding trees accounted for more than $60 \%$ of the total yield obtained from each family. Unfortunately, access to trained personnel and adequate germplasm is not always possible in cacao-producing regions to develop "hybrid seed." Clonal propagation methods such as air layering, rooted cuttings, and grafting have been used for multiplication and preservation of superior cacao genotypes, but these methods are time-consuming, may create incompatibility issues between scion and rootstock, or successful rooting of cuttings may be highly variable among genotypes and locations. Additionally, there is a concern with the true yield potential of cacao selections propagated by grafting onto a common rootstock. The overall yield potential of 40 promising cacao clones grafted onto the rootstock 'EET-400' and planted in replicated plots was only $32 \%$ when compared with the yield obtained from ungrafted trees (Irizarry and Goenaga, 2000).

The use of in vitro propagation methods for cacao production could contribute to efforts to improve yield per area, germplasm conservation, and rapid distribution of high-yielding clones (Maximova et al., 2008). Somatic embryogenesis using floral explants has been the only method successfully developed for the de novo regeneration of cacao plants in vitro (Maximova et al., 2008). 
Long-term field research is essential to demonstrate good yield performance of in vitro propagated cacao. Maximova et al. (2008) evaluated in St. Lucia nine cacao genotypes propagated in vitro by somatic embryogenesis for growth parameters for a period of 4.5 years. Their results indicated that somatic embryogenesis-derived plants showed normal phenotypes under field conditions and growth parameters similar to plants propagated by traditional methods such as rooted cuttings (Maximova et al., 2008). However, long-term yield data were not collected in that study.

The objective of this research was to evaluate yield performance of 12 cacao genotypes propagated by grafting and orthotropic rooted cuttings of somatic embryo-derived plants (SE-ORC) and grown under full sunlight and intensive management.

\section{Materials and Methods}

This study was conducted in Puerto Rico at the Corozal Agricultural Experiment Station of the University of Puerto Rico (Corozal clay: clayey, mixed, isohyperthermic Aquic Haplohumults). The soil has a $\mathrm{pH}$ of $4.47, \mathrm{NH}_{4}-\mathrm{N}$ $83 \mathrm{mg} \cdot \mathrm{kg}^{-1}, \mathrm{NO}_{3}-\mathrm{N} 74 \mathrm{mg} \cdot \mathrm{kg}^{-1}$, phosphorus $10 \mathrm{mg} \cdot \mathrm{kg}^{-1}$, potassium $353 \mathrm{mg} \cdot \mathrm{kg}^{-1}$, calcium $1293 \mathrm{mg} \cdot \mathrm{kg}^{-1}$, magnesium $79 \mathrm{mg} \cdot \mathrm{kg}^{-1}$, iron
$146 \mathrm{mg} \cdot \mathrm{kg}^{-1}$, manganese $19 \mathrm{mg} \cdot \mathrm{kg}^{-1}$, zinc $0.26 \mathrm{mg} \cdot \mathrm{kg}^{-1}$, aluminum $144 \mathrm{mg} \cdot \mathrm{kg}^{-1}$, and $1.41 \%$ organic carbon. The 64-year (1948-2012) mean annual rainfall is $1905 \mathrm{~mm}$ and Class A pan evaporation is $1433 \mathrm{~mm}$. Mean monthly maximum and minimum temperatures are 29.9 and $19.5^{\circ} \mathrm{C}$.

Ten-month-old trees of varieties 'TARS-1', 'TARS-2', 'TARS-13', 'TARS-14', 'TARS-15', 'TARS-21', 'TARS-23', 'TARS-30', 'TARS-31', 'UF-668', 'Pound-7', and 'Scavina-6' propagated by grafting and SE-ORC were transplanted to the field 31 July 2003 and arranged in a split plot design with five replications. Varieties 'TARS-1', '-14', '-15', '-23', '-30', and ' -31 ' were released in 2009 as high-yielding selections (Goenaga et al., 2009; Irizarry and Goenaga, 2000). Varieties 'TARS-2', 'TARS-13', and 'TARS-21' were among 40 selections evaluated during 1994-97 for high yield and adaptation to a typical tropical Ultisol soil (Irizarry and Goenaga, 2000). Cultivars UF-668, Pound-7, and Scavina-6 are three of the parental clones representing the original families from which the TARS cultivars were selected (Table 1; Irizarry and Goenaga, 2000). Each replication contained two main plots represented by trees propagated by grafting and SE-ORC. The main plots were split to accommodate 12 cultivars (subplots). Within a replication, plots for each cultivar contained two trees spaced $2.44 \mathrm{~m}$ apart and $3.05 \mathrm{~m}$ between adjacent rows forming a triangular array. Tree density was 1345 trees per hectare. The experiment was surrounded by a guard row of 'Amelonado' seedlings. Grafted trees were patch-grafted below the cotyledons onto 5-month-old open-pollinated 'EET-400' seedling rootstocks. For SE-ORC plants, immature flowers were collected from the mother trees in Puerto Rico (Irizarry and Goenaga, 2000) and transported on ice to Penn State University. The flowers were sterilized and staminodes and petal bases were dissected and cultured on tissue culture media for regeneration of somatic embryos using published protocols (Li et al., 1998, Maximova et al., 2002). Primary and secondary somatic embryoderived plants were acclimated and grown in the greenhouse at Penn State University and used for stock plants for propagation by orthotropic rooted cuttings (Maximova et al., 2005). Rooted SE-ORC plants from the 12 cultivars were returned to Puerto Rico as bare-root plants, 15 to $30 \mathrm{~cm}$ in height, and immediately planted in plastic bags and acclimated in a screenhouse until field transplanting.

The experiment was conducted under rain-fed conditions, but overhead irrigation was provided on 17 July 2009 and 20 June

Table 1. Yield comparison of 12 cacao clones and of three of their corresponding parental clones propagated by grafting and orthotropic rooted cuttings of somatic embryo-derived plants and grown under full sunlight and intensive management in Corozal, Puerto Rico, during a 6-year harvesting period (2007-12).

\begin{tabular}{|c|c|c|c|c|c|c|c|c|}
\hline \multirow{2}{*}{$\begin{array}{l}\text { Propagation } \\
\text { treatment }\end{array}$} & \multirow[b]{2}{*}{ Variety } & \multirow{2}{*}{$\begin{array}{l}\text { Family pedigree or } \\
\text { parental clone }\end{array}$} & \multicolumn{2}{|c|}{ Mean dry bean wt per year } & \multirow[b]{2}{*}{ Pod index } & \multirow{2}{*}{$\begin{array}{l}\text { No. of pods } \\
\text { (no./ha) }\end{array}$} & \multirow{2}{*}{$\begin{array}{l}\text { Plant } \\
\text { ht (m) }\end{array}$} & \multirow{2}{*}{$\begin{array}{c}\text { Stem } \\
\operatorname{diam}(\mathrm{cm})\end{array}$} \\
\hline & & & $\mathrm{kg} /$ tree & $\mathrm{kg} \cdot \mathrm{ha}^{-1}$ & & & & \\
\hline \multirow[t]{14}{*}{ Grafted } & TARS-1 & UF-668 × Pound-7 & 1.87 & $2,510.7$ & 24.7 & 58,552 & 2.52 & 10.3 \\
\hline & TARS-2 & UF-668 $\times$ Pound-7 & 1.75 & $2,353.1$ & 22.6 & 50,370 & 2.52 & 10.7 \\
\hline & TARS-13 & SCA-6 × EET-62 & 1.88 & $2,534.9$ & 41.4 & 102,646 & 2.65 & 12.1 \\
\hline & TARS-14 & SCA- $6 \times$ EET- 62 & 1.70 & $2,289.0$ & 31.9 & 72,630 & 2.74 & 12.3 \\
\hline & TARS-15 & SCA- $6 \times$ EET- 62 & 1.13 & $1,514.7$ & 40.2 & 57,701 & 2.96 & 13.6 \\
\hline & TARS-21 & UF-668 $\times$ Pound-7 & 1.51 & $2,025.1$ & 34.2 & 65,322 & 2.20 & 8.8 \\
\hline & TARS-23 & UF-668 $\times$ Pound-7 & 1.26 & $1,689.5$ & 23.4 & 34,365 & 2.48 & 9.9 \\
\hline & TARS-30 & SCA-6 $\times$ EET-62 & 1.86 & $2,496.3$ & 37.7 & 92,469 & 2.97 & 13.0 \\
\hline & TARS-31 & SCA- $6 \times$ EET -62 & 1.58 & $2,127.8$ & 41.6 & 86,797 & 3.01 & 12.3 \\
\hline & UF-668 & - & 2.02 & $2,717.2$ & 19.2 & 42,076 & 2.76 & 10.8 \\
\hline & Pound-7 & - & 1.37 & $1,841.9$ & 29.4 & 48,689 & 2.40 & 9.4 \\
\hline & SCA-6 & - & 1.41 & $1,900.6$ & 41.7 & 69,649 & 2.61 & 11.2 \\
\hline & Average & & 1.61 & $2,166.7$ & 32.3 & 65,105 & 2.65 & 11.2 \\
\hline & $\operatorname{HSD}(0.05)^{\mathrm{z}}$ & & 0.54 & 725.9 & 5.06 & 18,738 & 0.28 & 1.52 \\
\hline \multirow[t]{21}{*}{ SE-ORC } & TARS-1 & UF-668 $\times$ Pound-7 & 1.87 & $2,513.1$ & 27.9 & 67,407 & 2.75 & 12.9 \\
\hline & TARS-2 & UF-668 $\times$ Pound-7 & 1.53 & $2,062.9$ & 23.8 & 45,058 & 2.86 & 11.3 \\
\hline & TARS-13 & SCA-6 × EET-62 & 1.78 & $2,396.6$ & 46.3 & 108,183 & 3.10 & 13.2 \\
\hline & TARS-14 & SCA- $6 \times$ EET-62 & 1.89 & $2,542.9$ & 33.2 & 85,004 & 2.87 & 12.8 \\
\hline & TARS-15 & SCA-6 $\times$ EET-62 & 1.16 & $1,561.8$ & 45.9 & 65,322 & 3.11 & 13.9 \\
\hline & TARS-21 & UF-668 $\times$ Pound-7 & 1.44 & $1,942.9$ & 37.0 & 70,814 & 2.35 & 9.6 \\
\hline & TARS-23 & UF-668 $\times$ Pound-7 & 1.27 & $1,714.2$ & 24.7 & 41,426 & 2.72 & 10.6 \\
\hline & TARS-30 & SCA-6 × EET-62 & 1.91 & $2,565.4$ & 39.4 & 99,373 & 3.03 & 12.7 \\
\hline & TARS-31 & SCA- $6 \times$ EET- 62 & 1.12 & $1,501.1$ & 56.6 & 73,728 & 3.44 & 13.5 \\
\hline & UF-668 & - & 1.75 & $2,356.2$ & 22.7 & 42,211 & 2.81 & 10.4 \\
\hline & Pound-7 & - & 1.36 & $1,527.7$ & 33.5 & 49,362 & 2.66 & 10.7 \\
\hline & SCA-6 & - & 1.06 & $1,425.7$ & 49.1 & 66,734 & 2.80 & 11.5 \\
\hline & Average & & 1.51 & $2,009.2$ & 36.7 & 67,885 & 2.87 & 11.9 \\
\hline & HSD $(0.05)$ & & 0.40 & 537.9 & 9.44 & 16,187 & 0.22 & 1.10 \\
\hline & Year $(Y)^{y}$ & & $* * *$ & $* * *$ & $* * *$ & $* * *$ & $* * *$ & $* * *$ \\
\hline & Variety (V) & & $* * *$ & $* * *$ & $* * *$ & $* * *$ & $* * *$ & $* * *$ \\
\hline & $\mathrm{Y} \times \mathrm{V}$ & & $* * *$ & $* * *$ & $* *$ & $* * *$ & $*$ & NS \\
\hline & Propagation treatment (PT) & & $*$ & $*$ & $* * *$ & NS & $* * *$ & $* * *$ \\
\hline & $\mathrm{PT} \times \mathrm{Y}$ & & NS & NS & NS & NS & NS & NS \\
\hline & $\mathrm{PT} \times \mathrm{V}$ & & $*$ & $*$ & $* * *$ & $*$ & $* *$ & $* * *$ \\
\hline & $\mathrm{PT} \times \mathrm{Y} \times \mathrm{V}$ & & NS & NS & NS & NS & NS & NS \\
\hline
\end{tabular}

zTurkey's studentized range test at $P=0.5$.

$\mathrm{y}_{\mathrm{NS}}, *, * *, * * *$ Nonsignificant or significant at $P \leq 0.05,0.01$, or 0.001 , respectively, based on analysis of variance. 
2012 during periods of critical need. Fertilization was provided every 3 months using a $15 \mathrm{~N}-2.2 \mathrm{P}-16.3 \mathrm{~K}-1.8 \mathrm{Mg}$ commercial mixture at a rate of $1009 \mathrm{~kg} \cdot \mathrm{ha}^{-1}$. Because of the continued use of nitrogen fertilization with ammonium sulfate, the experimental trees were limed with calcium hydroxide at the rate of $1.4 \mathrm{~kg}$ in an area of $2.3 \mathrm{~m}^{2}$ under the tree canopy every 3 years. Herbicide (glyphosate) for weed control was applied only in strips within the planting row. After planting, trees were grown under temporary shade by placing $\mathrm{a} \approx 60-\mathrm{cm}$ tall shadecloth providing $30 \%$ shade and supported with two bent $0.95-\mathrm{m}$ steel rebars on the east side of plants for $\approx 6$ months at the end of which a row of tall, photoperiod-sensitive sorghum was grown on a row east of the cacao trees to provide some sun protection to cacao trees for an additional 5 months. Starting in 2006, in mid-June of each year, tree height was measured to the highest point and then trees were pruned to $3.0 \mathrm{~m}$. Trunk diameter was also measured in mid-June at $15 \mathrm{~cm}$ above the soil surface.

The white grub (Phyllophaga spp.), the most prevalent insect affecting cacao in Puerto Rico, was controlled with drenching the tree under the canopy with a solution of oxamyl containing $20 \mathrm{~mL}$ of commercial product per $4 \mathrm{~L}$ of water.

Fruit were harvested on a monthly basis. At each harvest the number of ripened pods per tree was counted and weighed. The pods were opened and the wet beans were extracted and fermented. Fermentation usually lasted 5 to $7 \mathrm{~d}$ and reached a maximum temperature of 40 to $45^{\circ} \mathrm{C}$. After fermentation, the beans were washed with a hose and sun-dried to $\approx 7 \%$ moisture content as determined by a DMC500 portable moisture tester (Seedburo Equipment Co., Des Plaines, IL). The pod index (number of pods needed to produce $1 \mathrm{~kg}$ of dry beans) was determined. Dried beans were sent to Mars Inc. for organoleptic evaluation of chocolate liquor samples from grafted and SE-ORC plants using the protocol of the Common Fund for Commodities/ International Cocoa Organization/Instituto Nacional Autónomo de Investigaciones Agropecuarias (CFC/ICCO/INIAP) Flavor Project (Sukha et al., 2008). Analysis of variance was carried out using the GLM procedure of SAS (Release 9.1 for Windows; SAS Institute, Cary, NC). After significant $\mathrm{F}$ test at $P \leq 0.05$, mean separation was performed with the Tukey's Studentized range test.

\section{Results and Discussion}

Pod harvest began in 2007 when all trees reached full production. Year, variety, the year $\times$ variety, and propagation treatment $\times$ variety interactions showed significant effects $(P \leq$ 0.05 ) for dry bean weight per tree, dry bean yield, number of pods per hectare, pod index, plant height, and stem diameter (Table 1). Propagation treatment did not have a significant effect on number of pods per hectare but had a significant effect on the rest of the variables. The propagation treatment $\times$ year and propagation treatment $\times$ year $\times$ variety interactions were not significant for any of the parameters measured in the study.

Overall varieties exhibited a significant increase in pod number and dry bean yield during the first 2 years (2007-08) after harvest began. Pod number and dry bean yield averaged 23,061 pods/ha/year and $836.5 \mathrm{~kg} \cdot \mathrm{ha}^{-1}$ per year, respectively, in 2007 and increased to $52,405 \mathrm{pods} / \mathrm{ha} /$ year and $1,557 \mathrm{~kg} \cdot \mathrm{ha}^{-1}$ per year, respectively, in 2008 (data not shown). Pod number and dry bean yield leveled off from 2009 to 2012 averaging $80,877 \mathrm{pods} / \mathrm{ha} /$ year and $2,469.3 \mathrm{~kg} \cdot \mathrm{ha}^{-1}$ per year, respectively (data not shown). This response is expected as trees increase in age; however, the magnitude of the response varied among varieties as expected by the significant year $\times$ variety interaction (Table 1 ). Overall, the months of higher pod production were April to May and November to December. The least productive months were July to September (data not shown).

Average dry bean yield across varieties in both propagation methods was $2087.9 \mathrm{~kg} \cdot \mathrm{ha}^{-1}$ per year (Table 1). 'UF-668', a United Fruits selection from Costa Rica (Phillips-Mora et al., 2007), was the top yielder averaging $2536.7 \mathrm{~kg} \cdot \mathrm{ha}^{-1}$ per year of dry beans (Table 1 ). However, this yield was not significantly different from the average yield of varieties 'TARS-30', 'TARS-1', 'TARS-13', 'TARS-14', and 'TARS-2', which averaged $2427.0 \mathrm{~kg} \cdot \mathrm{ha}^{-1}$ per year. Except for 'UF-668', the TARS varieties were released in 2009 as high-yielding selections (Goenaga et al., 2009; Irizarry and Goenaga, 2000).

Propagation treatment had a significant effect on dry bean yield and other variables measured in this study (Table 1). Dry bean yield of varieties propagated by grafting was $\approx 7 \%$ higher $\left(2166.7 \mathrm{~kg} \cdot \mathrm{ha}^{-1}\right.$ per year) than those propagated by SE-ORC (2009.2 $\mathrm{kg} \cdot \mathrm{ha}^{-1}$ per year; Table 1). This yield difference cannot be attributed to grafted plants being more vigorous as evidenced by the slight differences in average height and stem diameter of plants propagated by each method (Table 1). In fact, average plant height and stem diameter were higher in plants propagated by SE-ORC (Table 1). Visual observations of various trees excavated with a backhoe to a depth of $\approx 1.5 \mathrm{~m}$ at the end of the experimental period did not reveal differences in root depth or architecture among trees propagated by grafting or SE-ORC. A very superficial root system was characteristic of trees propagated by both methods. It is noteworthy that some trees propagated by SE-ORC showed a taproot-like structure, whereas others were missing it (Fig. 1A and B). A taproot is a desired phenotypic trait in trees grown in regions that are prone to be impacted by tropical storms and hurricanes because it helps to prevent tree lodging resulting from strong winds (greater than $105 \mathrm{~km} \cdot \mathrm{ha}^{-1}$ ). However, the taproot in grafted and SE-ORC trees can be lost in early growth stages as a result of poor tree management (e.g., length of time in the bag before transplanting, transplanting injury, etc.). Some of these factors may explain the absence of a taproot in some trees propagated by somatic embryogenesis. For example, the aluminum concentration in soil samples collected at a $1.5-\mathrm{m}$ depth during excavation of trees ranged from $592 \mathrm{mg} \cdot \mathrm{kg}^{-1}$ to $1216 \mathrm{mg} \cdot \mathrm{kg}^{-1}$. This aluminum concentration is very high and possibly inhibited the taproot from growing into the subsoil (Dipierro et al., 2005; Goenaga, 2011; Quinteiro-Ribeiro et al., 2013) where lime probably did not reach as evidenced by the high aluminum concentration. Similarly, over $115 \mathrm{~cm}$ of rain fell between July 2003 (planting time) and Dec. 2003. Furthermore, 2004 was also a very wet year with total rainfall exceeding $265 \mathrm{~cm}$. These amounts may have brought semianaerobic conditions in the soil, which could have affected taproot growth. Additional research under controlled conditions is needed to determine the frequency of the development of a taproot-like structure in cacao trees propagated by SE-ORC.

Among varieties propagated by grafting, 'UF-668' had the highest dry bean yield (2717.2 $\mathrm{kg} \cdot \mathrm{ha}^{-1}$ per year), but it was not significantly different from that of 'TARS-13', 'TARS-1', 'TARS-30', 'TARS-2', 'TARS-14', TARS-31', and 'TARS-21', which averaged $2334 \mathrm{~kg} \cdot \mathrm{ha}^{-1}$ per year. Among varieties propagated by SE-ORC, 'TARS-30' had the highest dry bean yield $\left(2565.4 \mathrm{~kg} \cdot \mathrm{ha}^{-1}\right.$ per year), but it was not significantly different from that of 'TARS-14', 'TARS-1', 'TARS-13', 'TARS-41', and 'TARS-2', which averaged $2374.3 \mathrm{~kg} \cdot \mathrm{ha}^{-1}$ per year (Table 1). Of the nine varieties released in 2009 as high-yielding (greater than $2000 \mathrm{~kg} \cdot \mathrm{ha}^{-1}$ per year) varieties (Goenaga et al., 2009), six ('TARS-1', 'TARS-14', 'TARS-15', 'TARS-23', 'TARS-30', 'TARS-31') were used in this study. When propagated by grafting in this study, these varieties had an average dry bean yield of $2111.1 \mathrm{~kg} \cdot \mathrm{ha}^{-1}$ per year, whereas when propagated by SE-ORC, these varieties had an average yield of $2066.4 \mathrm{~kg} \cdot \mathrm{ha}^{-1}$ per year (Table 1). These yields confirm for the first time since their release the high-yielding performance of these varieties in the absence of disease pressure except for black pod (Phytophthora spp.). Also, the yield similarity among varieties propagated by both methods rules out the possibility of yield reduction resulting from incompatibility between the scion and the rootstock, at least when 'EET-400' is used as the rootstock as it was the case in this and previous studies (Irizarry and Goenaga, 2000).

Propagation methods did not have a significant effect on the number of pods produced per hectare; however, the propagation treatment $\times$ variety interaction was significant (Table 1). Overall, varieties 'TARS-13' and 'TARS-30' produced a higher number of pods than other varieties in both propagation methods averaging 100,667 pods/ha/year. The lowest number of pods in both propagation treatments was obtained by 'Pound-7', 'TARS-2', 'UF-668', and 'TARS-23', which had a combined average of 44,195 pods/ha/year (Table 1).

Pod index is defined as the number of pods needed to produce $1 \mathrm{~kg}$ of dry beans. Therefore, a low pod index is a desirable 
varietal trait because it is associated with good bean size and a reduction in harvesting costs (Wood and Lass, 1985). In this study, propagation treatments had a significant effect on pod index (Table 1). Because number of pods was not significantly affected by propagation treatments (Table 1), the lower pod index and high yield obtained from grafted plants in this study can only be attributed to an increase in bean size. Increased bean size could be attributed to a more abundant root system, which may promote better absorption of soil nutrients and water and/or to higher photosynthetic capacity. However, visual differences in root architecture or abundance could not be established when trees from each propagation treatment were excavated. Similarly, higher photosynthetic rates could have resulted in more vigorous trees. In this study, however, values of plant height and stem diameter, which are traits related to tree vigor, were significantly lower in plants propagated by grafting than in those propagated by SE-ORC. Therefore, the reason for lower pod index values in grafted plants remains unclear. The variety with the lowest pod index in both propagation treatments was 'UF-668', averaging 20.9 (Table 1). However, pod index values for this variety did not differ significantly from pod index values in 'TARS-2' and 'TARS-23' in grafted plants and from 'TARS-2', 'TARS-23', and 'TARS-1' in plants propagated by SE-ORC. 'Scavina-6' had the highest pod index value in plants from both propagation treatments averaging 45.4 (Table 1). With the exception of 'TARS-23', all varieties having a low pod index (less than 25.0) such as 'UF-668', 'TARS-2', and 'TARS-1' also demonstrated superior dry bean yield (greater than $2000 \mathrm{~kg} \cdot \mathrm{ha}^{-1}$ per year; Irizarry and Goenaga, 2000). Daymond et al. (2002) proposed that potential yield improvements in cacao may be achieved by selecting varieties with a greater bean to pod ratio (i.e., lower pod index) such as that found for 'UF-668', 'TARS-1', and 'TARS-2' in this study.

Propagation treatments had a significant effect on plant height and stem diameter (Table 1). Among plants propagated by SE-ORC, trees of 'TARS-31' were significantly taller $(3.44 \mathrm{~m})$, whereas trees of 'TARS-21' were significantly shorter $(2.35 \mathrm{~m})$. A similar response was found for plants propagated by grafting, but, as expected by trees being grafted, there were fewer significant height differences among varieties (Table 1). It is noteworthy that 'TARS-1', in addition to being a top yielder and having a low pod index, also ranked among the shortest varieties (Table 1). These characteristics are all suitable for increased efficiency of orchard management. Stem diameter was significantly smaller in plants propagated by grafting than by SE-ORC. However, the magnitude of this difference was less than $1 \mathrm{~cm}$ (Table 1). Similar to the work carried out by Daymond et al. (2002), no correlation was found between stem diameter and yield (data not shown).
A total of 45 individual flavor attributes were analyzed in beans from varieties propagated by both methods. Each sample of chocolate liquor was tasted blind with five replications over a period of $9 \mathrm{~d}$. Of these 45 attributes, only 16 were associated with the cacao in this study (Table 2). The remainder of the attributes showed no response in the study indicating that these attributes were not a part of the flavor profiles of the clones evaluated. Except for total acidity, bitterness, astringency, fruit overripe, and total brown/ mature fruit, which had slightly lower but significant values in beans of plants propagated by SE-ORC, propagation methods did not have a significant effect on the remaining flavor characteristics of beans (Table 2). The possibility exists that beans from trees propagated by SE-ORC may have had a slightly higher tendency for increased extent of fermentation and, consequently, statistically significantly lower values for these flavor attributes. However, because the fermentation process in this experiment was not carried out under laboratory-controlled conditions, the authors cannot confirm a higher tendency for increased extent of fermentation in beans from plants propagated by SE-ORC. More importantly, although the differences obtained between both propagation methods

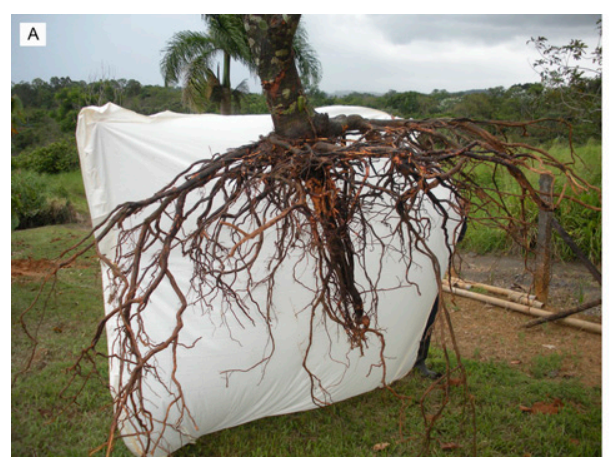

Fig. 1. Representative root system of cacao trees excavated to a depth of $\approx 1.5 \mathrm{~m}$ at Corozal, Puerto Rico. (A) Noticeable taproot-like structure on tree propagated by orthotropic rooted cuttings of somatic embryo-derived plants; (B) taproot-like structure is missing in tree propagated by orthotropic rooted cuttings of somatic embryo-derived plants.

Table 2. Mean chocolate flavor characteristics of cacao from trees propagated by grafting and orthotropic rooted cuttings of somatic embryo-derived plants in Puerto Rico during a 6-year harvesting period, $2007-12$.

\begin{tabular}{|c|c|c|c|}
\hline Flavor attribute & Grafted mean & Somatic embryogenesis mean & $P \geq F^{2}$ \\
\hline$\overline{\text { Cocoa }}$ & 6.90 & 7.01 & NS \\
\hline Total acidity & 0.36 & 0.14 & $*$ \\
\hline Bitterness & 4.44 & 4.34 & $*$ \\
\hline Astringency & 5.36 & 5.04 & $* * *$ \\
\hline Total fruit & 2.59 & 2.56 & NS \\
\hline Total fresh fruit & 0.36 & 0.52 & NS \\
\hline Total brown / mature fruit & 2.38 & 2.27 & $*$ \\
\hline Fruit dried & 0.82 & 0.58 & NS \\
\hline Fruit brown & 1.67 & 1.64 & NS \\
\hline Fruit overripe & 0.70 & 0.59 & $* * *$ \\
\hline Total floral & 3.31 & 3.20 & NS \\
\hline Floral herbal/earthy & 0.91 & 0.88 & NS \\
\hline Floral flowers & 0.27 & 0.27 & NS \\
\hline Dark wood & 2.49 & 2.51 & NS \\
\hline Bark wood & 1.30 & 1.31 & NS \\
\hline Dirty & 0.61 & 0.78 & NS \\
\hline
\end{tabular}

${ }_{\mathrm{NS}}, *, * * *$ Nonsignificant or significant at $P \leq 0.05$ or 0.001 , respectively, based on analysis of variance.

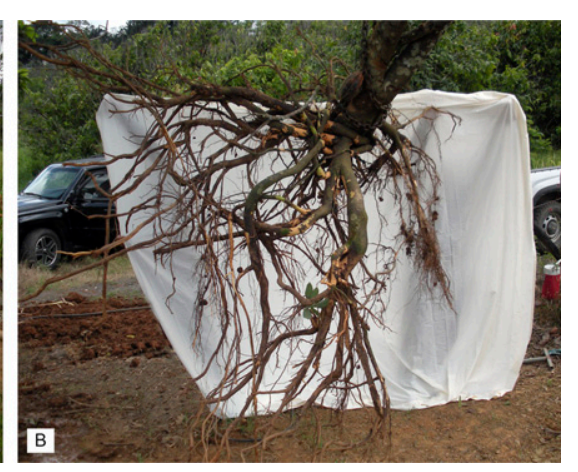

for total acidity (0.22), bitterness (0.10), astringency (0.32), total brown/mature fruit tically significant, these differences are very dustry standards. Normally, a difference of 1.0 to 1.5 units in any flavor characteristic would be considered meaningful from a taste andpoint (Seguine, unpublished data) plants propagated by somatic embryogenesis and SE-ORC (Maximova et al., 2008), this is the first study reporting long-term production quality traits of cacao trees propagated by grafting and SE-ORC. Although there were significant differences between plant propagation treatments for some of the variables measured in the study, these were extremely would preclude the implementation of somatic embryogenesis and consequent SE-ORC as a propagation system for cacao. Overall, in this study, plants propagated by SE-ORC
conformed to varietal phenotype, yield, and flavor quality attributes of cocoa as those prafting. Furthermore, many plants developed from SE-ORC produced taproot-like structures, which provide for tree $(0.11)$, and fruit overripe $(0.11)$ were statis- 
anchorage without the need of incurring in labor costs for grafting and in potential rootstock choupon management when trees become established in the field. Somatic embryogenesis in combination with SE-ORC also offers the advantage of being a propagation system with very large multiplication rates, which is a valuable characteristic for easy and fast distribution of genotypes. On the downside, some varieties propagated by somatic embryogenesis may not adapt well to the typical agroenvironment of the humid tropics (e.g., highly weathered, acid soils) where a tolerant rootstock may be the preferred option.

\section{Literature Cited}

Batista, L.J. 1981. Evaluación de Ia capacidad productiva de 6 híbridos de cacao en Ia Republica Dominicana. Proc. 8th International Cocoa Research Conference, Cartagena, Colombia. p. 713-717.

Daymond, A., P. Hadley, R.C.R. Machado, and E. Ng. 2002. Genetic variability in partitioning to the yield component of cacao (Theobroma cacao L.). HortScience 37:799-801.

Dipierro, N., D. Mondelli, C. Paciolla, G. Brunetti, and S. Dipierro. 2005. Changes in the ascorbate system in the response of pumpkin (Cucurbita реро L.) roots to aluminum stress. J. Plant Physiol. 162:529-536.

Enriquez, G.A. and A. Paredes. 1985. El cultivo del cacao. Serie: Cultivos mayores No. 4. Editorial. Univ. Estatal, San José, Costa Rica.

Enriquez, G.A. and J.V. Soria. 1984. Mejoramiento genético para resistencia a cinco enfermedades del cacao. Serie: Material de enseñanza No. 9. CATIE, Turrialba, Costa Rica.

Esquivel, O. and J.V. Soria. 1967. Algunos datos sobre Ia variabilidad de algunos componentes del rendimlento en poblaciones de híbridos interclonales de cacao. Cacao. Turrialba 12:1-8.

Goenaga, R., H. Irizarry, and B. Irish. 2009. TARS series of cacao germplasm selections. HortScience 44:826-827.

Goenaga, R.J. 2011. Dry matter production and leaf elemental concentrations of rambutan grown on an acid Ultisol. J. Plant Nutr. 34:753-761.

Hunter, J.R. 1990. The status of cocoa (Theobroma cacao, Sterculiaceae) in the Western Hemisphere. Econ. Bot. 44:425-439.

International Cocoa Organization. 2013. 9 Feb. 2014. <http://www.icco.org/about-cocoa/pesta-diseases.html>.

Irizarry, H. and R. Goenaga. 2000. Clonal selection in cacao based on early yield performance of grafted trees. J. Agr. Univ. P.R. 84:153-163.

Irizarry, H. and E. Rivera. 1998. Early yield of five cacao families at three locations in Puerto Rico. J. Agr. Univ. P.R. 82:163-171.

Li, Z.J., A. Traore, S. Maximova, and M.J. Guiltinan. 1998. Somatic embryogenesis and plant regeneration from floral explants of cacao (Theobroma cacao L.) using thidiazuron. In Vitro Cell. Dev. Biol. Plant 34:293-299.

Lindell, C. 2012. Report: $\$ 19.5$ billion in U.S. chocolate sales-And $20 \%$ growth in organic. 9 Feb. 2014. <http://www.candyindustry.com/ articles/print/85212-report-19-5-billion-inchocolate-sales-and-20 growth -in-organic $>$.

Maximova, S.N., L. Alemanno, A. Young, N. Ferriere, A. Traore, and M.J. Guiltinan. 2002. Efficiency, genotypic variability, and cellular origin of primary and secondary somatic embryogenesis of Theobroma cacao L. In Vitro Cell. Dev. Biol. Plant 38:252-259.

Maximova, S.N., A. Young, S. Pishak, and M.J. Guiltinan. 2008. Field performance of Theobroma cacao L. plants propagated via somatic embryogenesis. In Vitro Cell. Dev. Biol. Plant 44:487-493.

Maximova, S.N., A. Young, S. Pishak, C.R. Miller, A. Traore, and M.J. Guiltinan. 2005. Integrated system for propagation of Theobroma cacao, $\mathrm{p}$. 209-228. In: Jain, S.M. and P.K. Gupta (eds.). Protocol for somatic embryogenesis in woody plants. Springer, Dordrecht, The Netherlands.

Phillips-Mora, W., A. Mora, E.S. Johnson, and C. Astorga., C. 2007. Recent efforts to improve the genetic and physical conditions of the international cacao collection at CATIE. Proceedings of the International Cocoa Producer's Conference. San José, Costa Rica, 9-14 Oct. 1:611-623.

Quinteiro Ribeiro, M.A., A.A. Furtado de Almeida, M. Schramm Mielke, F. Pinto Gomes, M. Viana Pires, and V.C. Baligar. 2013. Aluminum effects on growth, photosynthesis, and mineral nutrition of cacao. J. Plant Nutr. 36:1161-1170.

Sukha, D.A., D.R. Butler, P. Umaharan, and E. Boult. 2008. The use of an optimized organoleptic assessment protocol to describe and quantify different flavour attributes of cocoa liquors made from Ghana and Trinitario beans. Eur. Food Res. Technol. Technol. 226:405-413.

Willson, K. 1999. Coffee, cocoa and tea. CABI Publishing, University Press, New York, NY.

Wood, G.A.R. and R.A. Lass. 1985. Cocoa. Longman, London, UK, and New York, NY. p. 8081. 